\title{
'Yes Scotland': More than a Party Political Campaign, a National Movement Fostering a New Active Citizenship
}

'Yes Scotland' : au-delà de la campagne des partis, un mouvement national appelant à un nouvel engagement des citoyens

Annie Thiec

\section{OpenEdition}

\section{Journals}

Electronic version

URL: http://journals.openedition.org/rfcb/401

DOI: $10.4000 /$ rfcb.401

ISSN: 2429-4373

\section{Publisher}

CRECIB - Centre de recherche et d'études en civilisation britannique

\section{Electronic reference}

Annie Thiec, «'Yes Scotland': More than a Party Political Campaign, a National Movement Fostering a New Active Citizenship », Revue Française de Civilisation Britannique [Online], XX-2 | 2015, Online since 23 July 2015, connection on 19 April 2019. URL : http://journals.openedition.org/rfcb/401 ; DOI : $10.4000 /$ rfcb.401

This text was automatically generated on 19 April 2019

\section{c) (†)}

Revue française de civilisation britannique est mis à disposition selon les termes de la licence Creative Commons Attribution - Pas d'Utilisation Commerciale - Pas de Modification 4.0 International. 


\title{
'Yes Scotland': More than a Party Political Campaign, a National Movement Fostering a New Active Citizenship
}

\author{
'Yes Scotland' : au-delà de la campagne des partis, un mouvement national \\ appelant à un nouvel engagement des citoyens
}

Annie Thiec

1 At the launch of the 'Yes Scotland' campaign in Edinburgh, on 25 May 2012, Scottish First Minister Alex Salmond acknowledged that in order for the campaign to win the case for independence it would have 'to galvanise the whole community of the realm of Scotland', and this, he argued, could only be achieved by building the campaign 'brick by brick, community by community, matching and marrying the sentiment of the people with the wonders of modern technology'. ${ }^{1}$ Adding that 'Yes Scotland' could find inspiration in the National Covenant ${ }^{2}$ of 1949 which had 'galvanised the Scots to sign for a Parliament', Alex Salmond set the target of one million signatures by the autumn of $2014^{3}$ to the 'Independence for Scotland' declaration to be posted online. Indeed he made the following claim: 'If we achieve that, then we shall win an independent Scotland", although strictly speaking one million votes in favour of independence on referendum day, out of a total of around 4 million registered voters, would not be sufficient to win the day.

2 The 'Independence for Scotland' declaration carried the main argument put forward by the supporters of independence, and described by the Scottish First Minister as ' $a$ declaration of self-evident truth', behind which all 'Yes' campaigners united, namely that the people who lived in Scotland were best placed to make the decisions that affected Scotland. ${ }^{4}$

3 Speaking just after the First Minister, Patrick Harvie, co-convener of the Scottish Green Party, pointed out that while many people had probably already made up their minds about how they were going to vote in the independence referendum, the main challenge 
for the 'Yes Scotland' campaign would be to rally the undecideds: 'If we're going to convince the unconvinced, we must build a clear and compelling vision of what will be different, of what independence is for, of how our society can change for the better'. ${ }^{5}$

'Yes Scotland', therefore, needed to capture the imagination of Scottish voters in a way that the National Conversation on the future of Scotland initiated by the first SNP Government in 2007 had not. ${ }^{6}$ In its second White Paper on the constitutional future of Scotland, 'Your Scotland Your Voice', published in 2009, the Scottish Government congratulated itself on the National Conversation being 'a unique programme of engagement with the Scottish public'. Yet its own official figures ${ }^{7}$ could hardly be seen as evidence that the objective of securing the 'fullest participation possible' set in the first White Paper, ' Choosing Scotland's Future: A National Conversation', had been met. ${ }^{8}$

The 1997 referendum was an obvious model for the Scottish Government, coming after the victory at the British general election of a party - Labour - which had committed itself in its election manifesto to a referendum on devolution. The devolution referendum had indeed given the Labour Government a clear mandate to proceed with its devolution plans. In 1997, however, the Labour Government could rely on the support of the other two parties in favour of constitutional reform, namely the Liberal Democrats and the SNP, all three parties campaigning alongside each other for a double 'Yes' vote' in the crossparty campaign 'Scotland FORward'. The three parties together commanded between two thirds and three quarters of the votes at every general election in Scotland from 1979 to 1992 and had won $80 \%$ of the votes in 1997. Besides, as opinion polls showed, the political consensus in favour of devolution was embraced by a large majority of the people of Scotland.

6 By contrast, by the time the SNP won its first Scottish Parliament election and formed a minority government in 2007, though there was a cross-party consensus on Scotland's constitutional future in the Scottish Parliament, it was against full independence. In fact, until 2007 there were two pro-independence parties other than the SNP represented in the Scottish Parliament, namely the Scottish Green Party and the Scottish Socialist Party, with respectively six and seven MSPs elected in 2003, but at the 2007 and 2011 Scottish Parliament elections, the Scottish Green Party only had two candidates elected - both on regional lists - while the Scottish Socialist Party did not manage to win a single seat. Besides, even after the SNP's historical victory in 2011, when the party won an overall majority of seats in the Scottish Parliament and won the election in 53 of the 73 constituencies, support for independence did not make any progress. As shown in the Scottish Social Attitudes surveys, a majority of people in Scotland were in favour of the powers of the Scottish Parliament being extended, but when it came to constitutional preferences they still opted for further devolution rather than complete independence. ${ }^{10}$

7 When the 'Yes Scotland' campaign was launched in the spring of 2012, therefore, victory seemed to be well beyond the reach of the three pro-independence parties. In actual fact, the target of 1million signatures to the 'Independence for Scotland' declaration was reached three and a half weeks before Referendum Day, on 22 August, but although the 'Yes' campaign gathered momentum in the last weeks of the official campaign and all the opinion polls showed the gap between the 'No' votes and the 'Yes' votes narrowing dramatically, the Scottish Government fell short of reaching the $50 \%$ needed to win the case for independence. On an exceptionally high turnout $-84 \%$ of the registered voters $55.3 \%$ said 'No' to Scotland becoming an independent country. 
8 Yet, in spite of the claims made by the leaders of the 'Better Together' campaign that the outcome of the referendum had settled the question of Scotland's independence once and for all, and while the Prime Minister announced on the day following the referendum the setting-up of an all-party commission chaired by Lord Smith and assigned the task of producing a set of proposals for more devolution by St Andrew's Day ${ }^{11}$, the proindependence movement has not died down - quite the reverse. One may wonder therefore to what extent 'Yes Scotland' could be seen as having laid the foundations for a national movement for independence.

9 Alex Salmond received most of the attention of the media in its coverage of the 'Yes Scotland' campaign from its launch in 2012 through to the final days of the official campaign. ${ }^{12}$ Yet, although the First Minister remained throughout 'the public face of the independence campaign', as David Torrance puts it,$^{13}$ in the last weeks of a campaign in which the pro-independence parties had to come to terms with a generally hostile media, the Scottish Green leader established himself more firmly in the party political campaign promoting his own vision of an independent Scotland. In actual fact, however, there were two campaigns developing in parallel, a campaign in the media which to a large extent was dominated by the SNP and a campaign on the ground, which involved a number of extra-parliamentary groups set up in the wake of the 2011 SNP election victory with a view to engaging people in the debate on what kind of society they wanted Scotland to be.

\section{The SNP-led campaign}

10 Great care was taken early on to make of 'Yes Scotland' an umbrella group rallying political parties, non-party organisations as well as individuals supporting independence, rather than a one-party campaign. A few weeks after the launch, Blair Jenkins, former head of news for both BBC Scotland and STV, was appointed as Chief Executive of 'Yes Scotland', ${ }^{14}$ and in August 2012 an advisory board of 10 members was appointed, half of whom were non-party political appointments. ${ }^{15}$ The composition of the board, chaired by former Labour MP and thereafter Independent MSP Dennis Canavan, scrupulously respected parity between men and women. Among its political appointments were the Deputy First Minister, Nicola Sturgeon, the co-convener of the Scottish Green Party, Patrick Harvie and the convener of the Scottish Socialist Party, Colin Fox.

11 Yet, just as the 'ScotlandFORward' campaign in 1997 had borne the mark of the Labour Party, regardless of the fact that both the Liberal Democrats and the SNP threw their weight behind a double 'Yes' vote, for the obvious reason that it was Labour in government in London which had decided to hold a referendum on devolution in the first place, the 'Yes Scotland' campaign was bound to bear the mark of the SNP. It was the SNP government which entered into negotiations with the British government over the right for the Scottish Government to hold a referendum on independence. It was Alex Salmond, as First Minister of Scotland, who signed the Edinburgh Agreement with the British Government on 15 October 2012 which, among other things, provided that the British Parliament would transfer to Holyrood the power to hold a referendum on independence before the end of 2014. And it was the Scottish Government which introduced legislation aimed at organising the referendum before the Scottish Parliament. ${ }^{16}$

12 As was the case in 1997, when the British Government published a White Paper ${ }^{17}$ ahead of the devolution referendum making the case for devolution, the Scottish Government also 
published a White Paper, Scotland's Future - Your Guide to an Independent Scotland, which was unveiled by the First Minister on 25 November 2013. In this case, however, not only did the White Paper make the case for independence but it also revealed in detail a number of policies which the SNP pledged to implement if it won the first general election in an independent Scotland. And although the White Paper did explain the difference between devolution and independence, and highlighted the gains from independence 'whichever party is elected', ${ }^{18}$ there was no doubt as to the fact that it was above all a policy document and looked very much like an election manifesto, unlike the British Government's 1997 White Paper on devolution which did not mention policies.

The SNP undoubtedly took advantage of its position as the governing party to rally people behind a 'Yes' vote thereby making the 'Yes' campaign appear very much as an SNP-led campaign. The Scottish all-women Cabinet chaired by Nicola Sturgeon in Edinburgh on 9 June 2014 is a case in point. Both the format of the Cabinet meeting, which included women from 130 organisations across Scotland, and the issues discussed on that occasion, whether it was the Government's commitment to free universal childcare for children aged 1 to $5^{19}$ or its proposal to raise the minimum wage, ${ }^{20}$ were clearly targeted at women, whom opinion polls had identified as being more reluctant to vote 'Yes' in the referendum. Indeed such events enabled the SNP to campaign for a 'Yes' vote while building on their record in government. ${ }^{21}$

In many instances, therefore, the leadership of the SNP - whether Alex Salmond or Nicola Sturgeon - seemed to be campaigning for the first election in an independent Scotland as much as for a 'Yes' vote in the referendum. Nowhere was this more evident than in the televised debates between Alex Salmond and Alistair Darling in August 2014, ${ }^{22}$ modeled on the leaders' debates first held in Britain during the 2010 general election campaign, and also held in Scotland in the run-up to the 2011 Scottish Parliament election. These two leaders' debates gave a presidential tone to the campaign, turning it into an election campaign in which voters were asked to choose between two parties to govern Scotland. This was inappropriate of course, but it was also hazardous, especially for the 'Yes' campaign as the message sent to the people was that a 'Yes' vote meant a vote for Alex Salmond.

15 While such a strategy may have paid off in the Scottish Parliament elections of 2007 and 2011, in the context of the referendum, it made the 'Yes' campaign run the risk of antagonizing people who might lean toward a 'Yes' vote but did not want to see Alex Salmond as the Prime Minister of an independent Scotland. Indeed Survation carried out an all-women poll for the Daily Record in which a sample of 1,000 women were interviewed between 8 and 12 August, that is to say between the two leaders' debates. ${ }^{23}$ Interestingly, the poll showed that while the SNP was the most popular party among women, support for the party leader was far from unanimous.

Thus, in terms of voting intentions in the 2016 Scottish Parliament election, the SNP came first: $43 \%$ of those certain to vote declared that they intended to vote for the SNP candidate in the constituency vote while $36.1 \%$ said they would vote for the SNP in the regional vote. ${ }^{24}$ Yet, a majority of the women interviewed (51.3\%) agreed with the statement that Alex Salmond's presence as leader of 'Yes Scotland' made them more likely to vote 'No' in the referendum. In fact, $55.3 \%$ thought that Alex Salmond wanted independence mainly because he wanted to be Prime Minister of an independent Scotland, while $44.7 \%$ thought that his motivation was that he thought independence would be best for the people of Scotland. Lastly, when it came to describing Alex 
Salmond's personality, the three most chosen adjectives were arrogant (54.6\%), ambitious (51.9\%) and dishonest (29.2\%). ${ }^{25}$

Besides, in the context of the 2011 Scottish Parliament election, the SNP leader had made the most of scoring political points during the leaders' debates by underlining his party's credentials as the most able party to defend the interests of Scotland within the United Kingdom and above all pressing his positive vision of the future against the negativity of his opponents. But this time the leaders' debates were at best a zero-sum game, since Alistair Darling outperformed Alex Salmond in the first debate, as Alex Salmond himself admitted afterwards, while the second debate turned to his own advantage.

Unsurprisingly therefore, the media coverage of the 'Yes' campaign focused very much on the SNP's proposals more than on independence as one constitutional option among others for the future of Scotland.

\section{Coming to terms with a generally hostile media}

The conventional media in Scotland was overwhelmingly opposed to independence. With the exception of the Sunday Herald, which called for a 'Yes' vote, all other Scottish newspapers - or Scottish editions - at best tried to present the two sides of the case, as did the Herald, but mostly defended the Union. Although some may at times have been critical of the strategy developed by the 'Better Together' campaign, all in all they had a definite bias against the 'Yes Scotland' campaign, and especially against the party seen as leading it, namely the SNP.

As a result of such hostility, the terms of the debate in the media were very much dictated by the parties defending the Union, from the outset right to the end of the campaign when, following a YouGov poll ${ }^{26}$ which gave the 'Yes' vote ahead of the 'No' vote, the British leaders of the three pro-Union parties, just a few days before the referendum, signed a joint statement committing themselves to a specific timetable for further devolution of powers to the Scottish Parliament if people voted 'No'. Long before the official campaign started, the issues which dominated the public debate were that of the currency which would be adopted in an independent Scotland, the question of whether or not an independent Scotland could be a member of the European Union, as well as oil and gas revenues and defence issues, including the question of whether or not an independent Scotland would be a member of NATO.

On all these issues, the 'Yes' campaign was shown in the media as being on the defensive most of the time, answering questions raised or reacting to attacks launched by their opponents against the vision they offered of an independent Scotland. As a matter of fact, even on unpopular policies decided in London, the 'Yes' campaign could be seen as losing ground, as was the case with the 'bedroom tax'. Indeed, when the British government announced early in February 2014 that power over housing benefit could be devolved in the event of a 'No' vote, the pro-independence parties found themselves deprived of one of their most popular arguments for independence, namely that only a 'Yes' vote could protect Scotland from policies being imposed on it by a coalition government it had not helped bring to power in London.

As the media chose to present a 'Yes' vote as expressing support for an SNP Government in an independent Scotland, the Scottish Government found itself driven into a corner. Thus, when on 12 February 2014, in Edinburgh, George Osborne, Chancellor of the 
Exchequer, ruled out a currency union between an independent Scotland and the rest of the UK, and was almost immediately backed by the Labour and the Liberal Democrat leaders, Alex Salmond was immediately pressed by the media to spell out his Plan B. Beside putting the SNP on the defensive, such pressure also brought to the fore dissensions within the 'Yes' campaign over the currency issue, between supporters of the Scottish Government's strategy of negotiating a currency union and advocates of a separate Scottish currency, among whom Patrick Harvie, but also Dennis Canavan, Jim Sillars and Colin Fox. Therefore although the idea of a currency union was strictly speaking what the SNP favoured, not what all the supporters of independence advocated, the decision by the three pro-Union parties to rule out a currency union was presented as exposing the weakness of the entire 'Yes' Campaign in a way that the differences between the proposals for further devolution to the Scottish Parliament made by the three proUnion parties were never presented in the media as a weakness of the 'No' campaign. In many ways, therefore, the 'Yes' campaign was presented in the media above all as a campaign led by the Scottish Government; consequently, the referendum was presented as a choice between accepting and refusing the political programme which an SNP Government would implement in an independent Scotland rather than as a choice between a devolved Parliament, possibly including an extension of its powers, and a fully independent Parliament.

Yet after the second leaders' debate on 25 August, as the 'Yes' vote started gathering momentum, ${ }^{27}$ a series of more conventional panel-based debates gave the Scottish Green Party co-convener, Patrick Harvie, the opportunity to voice his party's vision of an independent Scotland, which differed on some points from the vision expressed by the SNP, while also strongly making the case for a 'Yes' vote. In this regard, the second debate organised by STV on 2 September in Edinburgh, where he represented 'Yes Scotland' alongside the Deputy First Minister, Nicola Sturgeon, was emblematic of a new confidence and maturity in the 'Yes' camp. What came out of this debate first of all was that the two politicians campaigning for a 'Yes' vote were taking part in the debate on equal terms. In actual fact, not only did Patrick Harvie press his vision of an independent Scotland, but he had no qualms about expressing the divergences of opinion between his party and the SNP on some issues. Indeed he used these differences to make the point that the referendum was not a vote about getting Alex Salmond in or out of government, which, he argued, made the case for voting 'Yes' in the referendum even stronger.

In the same way, in the debate organised by the Herald in Glasgow on 4 September, ${ }^{28}$ the Green leader distanced himself from the SNP on the issue of oil, underlining the urgency in opting for renewable alternatives to fossil fuel energy. In fact he described oil as 'an asset but also a threat' and explained that although the Greens supported the removal of the Trident submarines from the Clyde estuary, they did not want to see nuclear submarines replaced with oil extraction off the west coast of Scotland. Patrick Harvie was also comfortable with highlighting the fact that the Green Party was in favour of an elected head of state, just as it did not want an independent Scotland to apply for membership of NATO.

In the end, the SNP, which had every legitimacy to set the agenda in the 'Yes' campaign being the party in government which had initiated the referendum, found itself constrained to some extent by its belief that the positivity of the message delivered by 'Yes Scotland' was what would win the case for independence. Building on the strategy it had developed during the 2011 Scottish Parliament election campaign, the SNP was 
determined to present a 'narrative of hope' to oppose to the negativity of the case made by the 'Better Together' campaign. Consequently, much stress was laid on the idea that the people who lived in Scotland were the best placed to make decisions affecting Scotland and that independence offered enormous opportunities in terms of economic prosperity and social justice, ${ }^{29}$ more than on a condemnation of the Westminster government.

As a result, the 'Yes' campaign faced a dilemma: the message had to be a positive message, but it also needed to appeal to people inclined to vote 'Yes' not so much because they adhered to the narrative presented by the SNP as because they felt that a 'No' vote meant approving the Westminster set-up. In other words, it needed to make sure that people inclined to say 'No' to the status quo could be persuaded to say 'Yes' to independence. And in spite of all the efforts made by the 'Yes' campaigners on the ground to show that a 'Yes' vote was not a vote for the SNP, this is what came out in the media.

In this regard, the campaign on the ground differed in many ways from the media campaign as it aimed at building on people's hostility to the Westminster political set-up, and more widely to the neo-liberal consensus in place at Westminster.

\section{The national movement behind 'Yes Scotland': a front against the neoliberal consensus at Westminster}

The 'Yes Scotland' campaign was remarkable in that it succeeded in engaging people in the debate about what kind of society they wanted Scotland to be, thanks, to a large extent, to the involvement of extra-parliamentary groups campaigning on the ground alongside party activists for a 'Yes' vote. These groups emerged within the left movement in Scotland, and positioned themselves firmly to the left of the Scottish Labour Party. In this regard, the profusion of publications centring on the potential for change in an independent Scotland bears witness both to the dynamism of the left movement and to the willingness to initiate a debate not so much on arguments in favour or against independence, as on different models of society. The titles of some of the books (Blossom What Scotland needs to Flourish, Caledonian Dreaming - The Quest for a Different Scotland, or Common Weal - All of Us First) published in the wake of the launching of the 'Yes Scotland' campaign are indeed emblematic of a feeling that the prospect of a referendum on independence gave the people of Scotland the opportunity to create a new nation and a new model of society. ${ }^{30}$

Among the non-partisan groups aiming at laying the foundations of a true participatory, citizen-engaging democracy one was actually created before the 'Yes Scotland' campaign was launched: 'National Collective' was founded in 2011 by a small group of artists and writers in Edinburgh. Presenting itself as 'the cultural movement for Scottish independence featuring artists, writers and activists creatively campaigning for a 'Yes' vote through local groups, events, social media, published word and art', its main objective was to help 'shape the vision of a new society and nation ${ }^{31}$ by providing a platform for individuals and local groups in the independence movement. People were therefore invited to participate in a variety of events, from debates and talks to cultural showcases and 'pop-up gigs', as well as sending their own contributions - visual or otherwise - to the National Collective website.

Three other extra-parliamentary groups actively campaigned on the ground for a 'Yes' vote, all aimed at engaging local communities across Scotland in the referendum debate 
by organising or taking part among other things in public meetings and street stalls. The 'Radical Independence Campaign' launched in Glasgow in November 2012 gathered trade unionists, socialists, environmentalists and anti-poverty campaigners whose objective was to promote a radical, progressive vision of Scotland. 'Women for Independence' was launched in September 2012 with a view to pursuing the work of the women's groups which in the 1990s had actively campaigned for equal representation of women in the

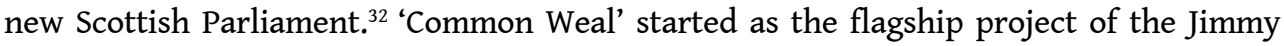
Reid Foundation in June 2013 which invited people to submit ideas about how to build a better, fairer society in an independent Scotland, and it became a separate organisation at the beginning of August 2014 .

The message they wanted to get across to the people in the run-up to and during the referendum campaign was that independence was not an end in itself, but rather it was an opportunity to reform and radically change Scottish society so as to establish a truly social democracy. Thus Cat Boyd and Jenny Morrison, both members of the Radical Independence Campaign, and authors of a pamphlet entitled Scottish Independence - a Feminist Response, explained that the question to answer was 'not whether Scotland should be an independent country, but how a 'Yes' vote could change the lives of Scottish women'. ${ }^{33}$ Independence was therefore a rational choice, not a nationalist one.

Their common aim was to build a front against the neo-liberal consensus in place at Westminster, which 'Common Weal' called the 'Me First' model. The point was not so much to convert a majority of the Scottish people to their proposals as to build on what they saw as having the potential of rallying an overwhelming majority of people in Scotland, namely 'the unsustainable direction of British capitalism'. ${ }^{34}$ For that purpose, what needed to be made clear to the electorate in Scotland was that the 'No' campaign embodied 'the status quo of the Westminster-style government' ${ }^{35}$ It was therefore absolutely essential for 'Yes Scotland' to 'present a positive alternative to blackmail of Westminster-style neoliberalism with its stark message of "there is no alternative". ${ }^{36}$

Presenting a positive alternative, however, did not preclude condemning the neo-liberal consensus itself - quite the reverse. In this regard, Britishness was seen by the Radical Independence Campaign as 'the missing link in the Yes campaign'. ${ }^{37}$ In other words, it was vital to put forward the case against the status quo as much as the case for independence. As James Foley and Pete Ramand put it: 'Our task in common, across the 'Yes' movement, is convincing the Scots that they lose out from attachments to Britain'. ${ }^{38}$ The crucial question, therefore, was 'can Scotland afford to stay in Britain?' and not 'can Scotland afford to go it alone?'. ${ }^{39}$ Likewise, Alan Bisset explained in an essay published in 2012 in the collection of essays entitled Unstated - Writers on Scottish Independence: 'For the Yes campaign to be successful, Scots will need to recognize in it a sense of their own grievance [...]. We must talk the language of hurt as much as the language of hope. ${ }^{40}$

It was essential therefore to build a positive message on what Scotland would lose if it chose to stay in the United Kingdom, in an attempt at making the Scots feel less attached to the Union. Instead of presenting the prospect of an independent Scotland exclusively in terms of opportunities offered which would guarantee economic prosperity and social justice, as the Scottish Government tended to do when it insisted on delivering a 'narrative of hope' to counterbalance the negativity of the 'Better Together' campaign, it was equally important to underline the fact that a 'No' vote meant more austerity and more cuts in public services. In actual fact, this is a point which the 'Radical Independence Campaign', as well as 'Women for Independence' and 'Common Weal' tried 
to address in the public meetings and events they organized or took part in, thereby trying to expose the promises for further devolution made by the pro-Union parties as being aimed at legitimizing the Westminster model of government.

What also made the campaign on the ground particularly invigorating and dynamic was the fact that it combined conventional ways of campaigning, such as leafleting and canvassing on the doorsteps, as well as traditional forms of citizen engagement through the town hall meetings, with the tools of modern technology. This undoubtedly contributed to the sense of massive citizen engagement generated by 'Yes Scotland'. To take one example, National Collective launched a Twitter hashtag called '\#YesBecause' which encouraged people to declare themselves for independence, and which could be used to a certain extent as a new kind of canvassing. Besides, the 'Yes' campaign also had its own media in the form of the online newspaper and website Bella Caledonia, which published articles aimed at balancing the bias of the conventional media against independence. ${ }^{41}$ Likewise, during the Edinburgh Festival, a new online television channel appeared on the Internet which called itself Referendum TV. It was created and run by volunteers who felt that the mainstream media were not telling the whole story in the referendum debate, and that the mainstream broadcast media, and the BBC in particular, could not be trusted to tell the truth in spite of its neutrality obligation. Among the programmes webcast during the campaign, mostly in August, were face-to-face interviews as well as informal debates with a variety of guests from all walks of life, not all of them in favour of a Yes vote. ${ }^{42}$

When it comes to assessing the potential impact modern technologies and in particular the social media may have had on the campaign, caution is required, however. Research carried out by Mark Shepard and Stephen Quinlan on the role of the social media in the referendum campaign over a period of one year from mid-August 2013 to the referendum has established that, although online activity increased considerably on both sides of the debate, especially in the last three weeks of the campaign, 'Yes Scotland' had won the social media campaign in terms of the number of followers on its Twitter account, of the number of likes on its Facebook page as well as of the number of comments posted on it. Yet, although 'Yes Scotland' generated greater enthusiasm online than its rival, this was not reflected in the polls ${ }^{43}$ which still showed the 'No' vote as being ahead of the 'Yes' vote. According to Stephen Quinlan, this could be explained by the fact that 'the social media world is one where the committed interact with each other rather than one where converts are made.$^{44}$ Indeed, the first poll carried out by TNS after the referendum, in mid-October, confirmed that caution was required when trying to assess the influence the social media may have had on the outcome of the referendum: it showed indeed that only a small percentage of people had contributed to an online discussion (11\%) compared to the proportion of people who had watched television $-60 \%$ of the people interviewed had watched one of the two television debates - or talked about the referendum with their friends and family (62\%).

\section{Conclusion}

When asked by Andrew Marr a few days before the referendum whether he would be satisfied that independence was the settled will of the people of Scotland if the 'Yes' campaign won by only a few votes, Alex Salmond replied: 'One of the great assets of the 'Yes' 
campaign is that we tend to take the attitude that there is not so much as a 'No' vote in Scotland, there are only deferred Yeses. ${ }^{45}$

While such comment could be derided as a sign of arrogance, it is interesting, however, for two reasons: first, it indicated that the SNP leader had already accepted the idea that the outcome might be a 'No' vote and was looking ahead, beyond the referendum; besides, if one considers the developments in the last days of the campaign when the leaders of the three main British parties signed a joint statement committing themselves to further devolution in case of a 'No' vote, one may wonder what proportion of the electorate may have decided to vote 'No' in the end because of the pledge made by David Cameron, Nick Clegg and Ed Miliband. Indeed a British Election Study poll carried out between 20 February and 9 March 2014 showed that three quarters of the Scots wanted more devolution, and while unsurprisingly $96 \%$ of the people who intended to vote 'Yes' wanted to see more powers devolved to the Scottish Parliament, even among the 'No' voters $57 \%$ of the people interviewed also shared that view.

The percentage of 'Yes' votes in the referendum - 44.7\% - could therefore be indicative of a breakthrough in the building up of a national movement for independence. In any case, the fact that, within a couple of weeks of the referendum, the membership of the SNP and that of the Scottish Green Party tripled to reach 75,000 and 6,000 respectively, while the Scottish Socialist Party also registered an increase in membership, is evidence that the referendum has not settled the question of Scotland's independence. The membership figures unveiled by both parties at the end of the year 2014 - over 93,000 members for the $\mathrm{SNP}^{46}$ and 7,500 for the Scottish Green Party ${ }^{47}$ - confirm that the independence movement has not lost momentum in the wake of the referendum.

As a matter of fact, just over four months after the referendum, the 'Radical Independence Campaign', 'Women for Independence' and 'Common Weal' have already set themselves further objectives: the 'Radical Independence Campaign', in a postreferendum statement issued on 27 September and entitled 'Moving Forward', pledged to 'act as a broad movement for change that continues to promote the idea that another Scotland is possible ${ }^{48}$ and has committed itself to continuing to work with the independence movement. 'Women for Independence' have decided to turn their campaign into a formal organization and will hold their first AGM on 14 March 2015. Meanwhile 'Common Weal' is looking ahead to the forthcoming 2015 general election campaign and has launched its 'red lines campaign' aimed at encouraging people to vote for small parties which in the context of a 'hung' parliament could hold the London government to account.

\section{BIBLIOGRAPHY}

BOYD, Cat \& MORRISON, Jenny. Scottish Independence: A Feminist Response. Edinburgh: Word Power Books, 2014.

FOLEY James \& RAMAND, Pete. Yes - The Radical Case for Scottish Independence. London: Pluto Press, 2014. 
HAMES, Scott (ed). Unstated - Writers on Scottish Independence. Edinburgh: Word Power Books, 2012.

HARVEY, Malcolm \& LYNCH, Peter. "Inside the National Conversation: The SNP Government and the Politics of Independence 2007-2010”, Scottish Affairs, n80, summer 2012, pp.91-116.

HASSAN, Gerry. Caledonian Dreaming - The Quest for a Different Scotland. Edinburgh: Luath Press, 2014.

JIMMY REID FOUNDATION, Common Weal - All of Us First, Glasgow: Thomson printers, 2014.

QUINLAN, Stephen. "Racing Ahead Online: Catching Up Offline?", posted on the “What Scotland Thinks' blog, 21 February 2014.

RIDDOCH, Lesley. Blossom - What Scotland needs to Flourish. Edinburgh: Luath Press, 2013.

SCOTTISH GOVERNMENT. Your Scotland, Your Voice. November 2009.

SCOTTISH GOVERNMENT. Choosing Scotland's Future: A National Conversation - Independence and Responsibility in the Modern World. August 2007.

SCOTTISH GOVERNMENT. Scotland's Future - Your Guide to an Independent Scotland. November 2013.

SHEPARD, Mark. "So who is Winning the Enthusiasm Race? The Visibility of the Two Campaigns on Social Media”, posted on the 'What Scotland Thinks' blog, 6 November 2013.

SHEPHARD, Mark. "Is the 'Yes' Online Tsunami Finally Paying Dividends?", posted on the "What Scotland Thinks' blog, 16 September 2014.

TORRANCE, David. "Referendum Debate: Year Two”, Scottish Affairs, n84, summer 2013, pp.17-40.

\section{NOTES}

1. <https://www.youtube.com/watch?v=2kFXj55g3yU>, accessed 22 January 2015.

2. The National Covenant was launched in October 1949 at the cross-party Scottish Convention initiated by John MacCormick in 1942 and aimed at gathering support for Home Rule. The Covenant did not call for full independence, but rather for the establishment of a Scottish Parliament within the framework of the United Kingdom. Although the number of signatories has been disputed, some estimates putting that number at over two million people, bearing in mind that the population of Scotland was around 5.1 million according to the 1951 census, it was undeniably successful as a mass petition albeit one which had little political impact .

3. The date of the referendum had not been set yet. On 10 January 2012, the British Government launched a consultation on handing temporary powers to the Scottish Parliament to organise a referendum on independence, the preferred date for the British Government being 2013. The following day, however, Alex Salmond announced that his preferred date was the autumn of 2014.

4. The text of the Declaration for Independence read as follows:

'I believe it is fundamentally better for us all, if decisions about Scotland's future are taken by the people who care most about Scotland, that is, by the people of Scotland.

Being independent means Scotland's future will be in Scotland's hands.

There is no doubt that Scotland has great potential. We are blessed with talent, resources and creativity. We have the opportunity to make our nation a better place to live, for this and future generations. We can build a greener, fairer and more prosperous society that is stronger and more successful than it is today.

I want a Scotland that speaks with her own voice and makes her own unique contribution to the world: a Scotland that stands alongside the other nations on these isles, as an independent nation.

5. <https://www.youtube.com/watch?v=2kFXj55g3yU>, accessed 22 January 2015. 
6. Malcolm HARVEY \& Peter LYNCH, "Inside the National Conversation: The SNP Government and the Politics of Independence 2007-2010", Scottish Affairs, n80, summer 2012, pp.91-116.

7. SCOTTISH GOVERNMENT, Your Scotland, Your Voice, November 2009, pp.5-6. The Government claimed that more than 15,000 people had engaged in the National Conversation overall over the two-year period: over 5,300 people had attended more than 50 National Conversation events, more than 6,500 people had attended 130 economy-based sessions, and almost 5,000 people had posted comments on National Conversation blogs. As for the National Conversation website it had received 500,000 hits.

8. SCOTTISH GOVERNMENT, Choosing Scotland's Future: A National Conversation - Independence and Responsibility in the Modern World, August 2007, p.38.

9. Two questions were put to the people of Scotland in the referendum, the first on whether they agreed that Scotland should have a devolved parliament and the second on whether they agreed that the Scottish Parliament should be granted tax-varying powers.

10. The percentage of people opting for independence when asked about their constitutional preference averaged $26.5 \%$ between 2007 and 2013 never reaching the 30\% mark except in 2011 with $32 \%$ declaring themselves in favour of full independence. See Scottish Social Attitudes Surveys 2007-2013.

11. In the last days of the campaign the British leaders of the three main parties involved in the Better Together campaign signed a joint statement in which they promised that if the Scots said 'No' to independence, then they would deliver more powers to the Scottish Parliament.

12. David TORRANCE, "Referendum Debate: Year Two", Scottish Affairs, ${ }^{\circ} 84$, summer 2013, p.21.

13. The 16-week official campaign started officially on 30 May 2014.

14. Yes Scotland opened its headquarters in Glasgow in November 2012.

15. Andrew Fairlie (renowned Scottish chef), Elaine C Smith (actress), Pat Kane (musician), SarahJane Walls (fitness trainer and businesswoman), Dan MacDonald (businessman) and Ellie Koepplinger (senior pupil). The appointment of 16-year-old Ellie Koepplinger was all the more remarkable as the question of whether or not 16-and 17-year-olds would be enfranchised for the referendum had not yet been settled.

16. The Scottish Independence Referendum (Franchise) Bill was introduced on 11 March 2013 and was passed on 27 June 2013, while the Scottish Independence Referendum Bill was introduced on 21 March 2013 and passed on 14 November 2013.

17. SCOTTISH OFFICE, Scotland's Parliament, Cm.3658, London: HMSO, July 1997.

18. SCOTTISH GOVERNMENT, Scotland's Future - Your Guide to an Independent Scotland, November 2013, p.xii.

19. Alex Salmond had announced extra childcare and free school meals for all pupils from Primary 1 to 3 as from January 2015.

20. Women are generally speaking more likely to be in low-paid jobs.

21. In the same way the Youth Cabinet held in Glasgow on 20 June 2014 in which over 100 young people were given the chance to question ministers about their plans for an independent Scotland was clearly targeted at young voters, and especially at the 16-17 year olds who thanks to legislation introduced by the Scottish Government were allowed to vote in the referendum.

22. The first debate was broadcast on STV on 5 August while the second was broadcast on the BBC on 25 August.

23. Scottish Attitudes Poll (August): A Poll of Scottish Women, 14 August 2014. <survation.com/ wp-content/uploads/2014/08/Scottish-omnibus-August-Daily-Record.pdf>, accessed 22 January 2015.

24. The Labour Party came second with respectively $26.8 \%$ and $22.9 \%$ of voting intentions.

25. When presented with the same list of adjectives, the question this time being asked about Alistair Darling, the three most chosen words were 'intelligent' (42.7\%), 'principled' (34\%) and 'arrogant' (30.7\%). 
26. A YouGov poll for the Sunday Times on 7 September showed the 'Yes' vote at $51 \%$ and the 'No' vote at $49 \%$.

27. From a 22-point lead in the polls for the 'No' vote over the 'Yes' vote at the beginning of August, the gap between 'No' and 'Yes' had narrowed to a 14-point lead by mid-August, and by the end of the month it was down to a 6-point lead.

28. The SNP was represented in the debate by Fiona Hyslop, Cabinet Secretary for Culture, Europe and External Affairs.

29. Such positivity was epitomised by the 'Declaration of Opportunity' made by Alex Salmond in Arbroath on 18 August, that is to say one month before Referendum Day.

30. Lesley RIDDOCH, Blossom - What Scotland needs to Flourish, Edinburgh: Luath Press, 2013; Gerry HASSAN, Caledonian Dreaming - The Quest for a Different Scotland, Edinburgh: Luath Press, 2014; JIMMY REID FOUNDATION, Common Weal - All of Us First, Glasgow: Thomson printers, 2014.

31. <Erreur ! Référence de lien hypertexte non valide. accessed 22 January 2015.

32. Among its founding members were Carolyn Leckie and Rosie Kane, both former Scottish Socialist MSPs, Natalie McGarry, member of the SNP, and Jeane Freeman, former political adviser to Jack McConnell when he was First Minister.

33. Cat BOYD \& Jenny MORRISON, Scottish Independence: A Feminist Response. Edinburgh: Word Power Books, 2014, p.8.

34. James FOLEY \& Pete RAMAND, Yes - The Radical Case for Scottish Independence, London: Pluto Press, 2014, p.123.

35. Pete RAMOND \& James FOLEY, “A Winning Strategy for Independence?”, posted on the Bellacaledonia website, 27 May 2012. <http://www.bellacaledonia.org.uk/2012/05/27/a-winningstrategy-for-independence>, accessed 22 January 2015.

36. Ibid.

37. James FOLEY \& Pete RAMAND, Yes - The Radical Case for Scottish Independence, op.cit., p.13.

38. James FOLEY \& Pete RAMAND, Ibid., p.86.

39. Ibid., p.88.

40. Alan BISSET in Scott HAMES (ed), Unstated - Writers on Scottish Independence, Edinburgh: Word Power Books, 2012, p.38.

41. Bella Caledonia was actually created in 2007 as an online newspaper and website whose objective was to be different from the mainstream media which considered citizens as the passive recipients of information, and to encourage instead a new participatory citizenship.

42. Several of these debates were hosted by renowned Scottish journalists and broadcasters, among whom Lesley Riddoch and Iain Macwhirter,

43. Mark, SHEPHARD, "Is the 'Yes' Online Tsunami Finally Paying Dividends?", posted on the 'What Scotland Thinks' blog, 16 September 2014. <http://blog.whatscotlandthinks.org/2014/09/ yes-online-tsunami-finally-paying-dividends> accessed 22 January 2015.

44. Stephen QUINLAN, "Racing Ahead Online: Catching UP Offline?", article posted on the "What Scotland Thinks,' blog, 21 February 2014. < http://blog.whatscotlandthinks.org/2014/02/racingahead-online-catching-up-offline> accessed 22 January 2015.

45. BBC ONE, The Andrew Marr Show, 14 September 2014. The polls at that stage of the campaign predicted that the referendum result would be a very close call.

46. Figures available at the following website address: <http://www.snp.org/?q=media-centre/ news/2014/dec/new-snp-members-improve-gender-balance-party>, accessed 22 January 2015.

47. Figures available at the following website address: <http://www.greenparty.org-uk/ news/2014/12/11/green-surge-green-party-polling-in-fourth-again>, accessed 22 January 2015.

48. <http://radicalindependence.org/2014/09/28/ric-statement-moving-forward/>, accessed 22 January 2015. 


\section{ABSTRACTS}

In its coverage of the 'Yes Scotland' campaign the media focused very much on the Scottish National Party's proposals for an independent Scotland, thereby presenting the 'Yes' campaign as being led by the Scottish Government, rather than discuss independence as one constitutional option among others for the future of Scotland. Yet, in spite of the claims made by the leaders of the 'Better Together' campaign that the $55.3 \%$ of 'No' votes in the referendum settled the question of Scotland's independence once and for all, the independence movement has not lost momentum. This article seeks to demonstrate that although 'Yes Scotland' unsurprisingly bore the mark of the SNP, the campaign on the ground, which alongside party activists involved extraparliamentary groups whose ambition was to engage people in a wider debate on what kind of society they wanted Scotland to be, can be seen as having laid the foundations for a national movement for independence.

Dans leur présentation de la campagne pour le «oui », les médias se sont principalement intéressés à une analyse du projet politique du Scottish National Party, suggérant ainsi que la campagne était dirigée par le gouvernement écossais, plus qu'ils n'ont débattu de l'indépendance comme une option constitutionnelle parmi d'autres pour l'avenir de l'Écosse. Pourtant, même si les chefs de file de la campagne pour le 'Non' ('Better Together') ont affirmé que le résultat du référendum ( $55.3 \%$ de «non ») avait réglé la question de l'indépendance de l'Écosse une fois pour toutes, le mouvement pour l'indépendance n'a pas perdu de sa vigueur. Le présent article vise à démontrer que, bien que 'Yes Scotland' ait porté la marque du SNP, la campagne sur le terrain, dans laquelle se sont engagés aux côtés des partis politiques plusieurs collectifs ayant pour objectif d'encourager les citoyens à débattre du type de société qu'ils souhaitaient pour l'avenir, peut être analysée comme ayant posé les fondements d'un mouvement national pour l'indépendance.

\section{INDEX}

Keywords: 'Yes Scotland' campaign, SNP strategy, citizen engagement, national independence movement

Mots-clés: campagne pour l'indépendance, stratégie du Parti national écossais, engagement citoyen, mouvement national pour l'indépendance

\section{AUTHOR}

\section{ANNIE THIEC}

Université de Nantes 